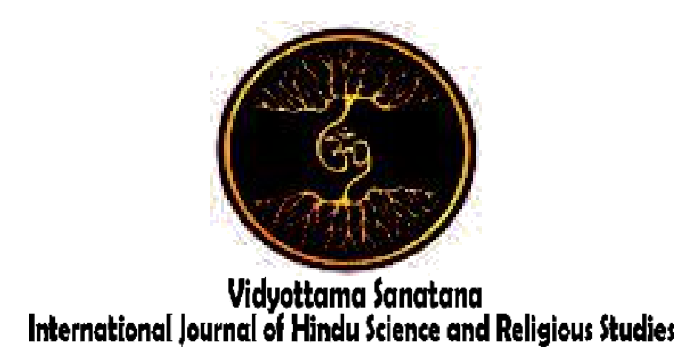

Vol. 3 No. 2 October 2019

\title{
THE UTILIZATION OF SCREENCAST O MATIC APPLICATION AS A MEDIUM IN THE HINDU RELIGIOUS LEARNING PROCESS
}

\author{
By: \\ Ida Ayu Kartika Dewi, I Nyoman Temon Astawa, I Nyoman Sueca, \\ Ni Wayan Desi Yuliantari \\ Institut Hindu Dharma Negeri Denpasar \\ E-mail : desiyuliantari24@gmail.com
}

Received: May 21, 2019

Accepted: August 28, 2019

Published: October 31, 2019

\begin{abstract}
Education is one of the most important things when plunging into the society, no exception when it comes to religion. Definition of how important education and religion are inseparable. They who embraced the Hindu taught about their beliefs through formal education in schools, but there are always shortages that make the educational levels of our religion becomes very low. And one of the problem is the process of learning theory and practice in Hindu religious are rated more boring because it contains lectures and stories. Besides, the education system in our country has too many anomalies since the beginning. One example is the system want to spawn a quality product, but they did not consider the best time per subject for students studying in the school. And also, as an educator, there are many things that can happen that make their time to teaching students with face-to-face is lost. Have workshops, go to meetings and fulfill their administrative duties as educators who make their exclusion of students. This is a system that shows the lack of quality of learning but educators would like to encourage the students involved in the process of learning to make it work. Here, the author would like to give a simple solution of saving time educators without lowering the quality time to teach and skipped a meeting at school. This application named Screencast $O$ Matic.
\end{abstract}

Keywords: Matic Application, Hindu Religious, Learning Process

\section{INTRODUCTION}

Education in Indonesia have a system that can be roughly represented by skyscrapers but do not have paw that are strong enough to climb the sky itself. Related to the skyscraper, paw is the foundation that 
supposed to be built with stronger so when climbing the sky, there will be a fall in the middle of the journey. Similarly, with the education system in Indonesia, many systems are always on trial, every turn of the Prime Minister of education, then there will be a new education system that will be on trial again, many qualities to be achieved and presented in the system, to achieve that quality is less accompanied by the balancing of the system structure itself.

Hindu religious education is to nurture all efforts of humanity, as well as the existing human resources leading to the formation of the whole person in accordance with the norms of the prevailing society. Thus, the purpose of the Hindu religious education focuses on three dimensions, namely: first, the formation of civilized human beings (human universal, consciousness). Second, the creation of religious beings, which has dimensions of spiritual, cultural, and scientific. Thirdly, awareness of human function as human beings, give adequate provision in the framework of the implementation of the function. The purpose of the Hindu religious education will be achieved when the selected educational material and taught with good precision.

Indonesia is still in a developing country and its development has not been evenly distributed, not all parts of the territory of Indonesia gets higher-education. Not all schools in Indonesia has adequate quality of education as mentioned in the system. One is the existence of facilities and facilitators themselves. Facilities were not built properly on each of the schools, especially schools that are in remote areas or underprivileged schools, causing many of the constraints that make the system not running in the middle of its application [3]. So it is with the facilitator, or in this case the main facilitator of an education system is the teacher itself.

So many kinds of people, then many types of teachers. Many teachers are really devoted themselves to educate, but not a few others only come to teach just for bite of rice. But it is not a thing that ought to be blamed given Indonesia more emphasis on quantity rather than quality. For a teacher who really wants to devote himself to educate is now increasingly complicated by the many administrative requirements of the government that must be met by an educator in order to remain able to do their duty in providing knowledge to the students, so inevitably many of the educators who put aside their students in order to qualify the administrative requirements and lost face-toface hours with students.

The number of teachers who are qualify the administrative requirements, so their students only given tasks without any more detailed explanations of the material [4]. Latest Indonesia education system indeed require students to apply cognitive learning theory advanced by Jerome Bruner who found the discovery learning method or student be required to seek the information and data as many about the material being discussed, but the teacher also has a duty as a facilitator to explain in advance about the material in question, either understanding or its parts and the teacher actually lost many opportunities because of obligations outside of the lessons that have to be done to qualify the administrative requirements as educators.

\section{RESULT AND DISCUSSION \\ 2.1. Application Screencast $O$ Matic}

Screencast O Matic is a Java-based application that is used to create screencasts or might be called screen recorders on Windows, Mac, and Linux. Screencast O Matic provides free software that allows users to record all views and movements of the monitor screen, be it cursor movements and click indicators, which then can also easily to use, then can be add captions and comments easily. Videos that have been created can be saved in the format MP4, AVI, FLV and then uploaded to Screencast O Matic, web space or YouTube.

Screencast-O-Matic is the application of screen capture recording, which can record the computer screen with one click and can quickly and easily record your screen to create video tutorials or help videos. This 
application also offers free hosting for videos we make and Screencast-O-Matic captures the screen and Webcam video then save it and can be posted online on YouTube or the program website with a well designed interface and simple operation.

This free screenshot application can be downloaded on the internet is also a fun and easy to used by the student to make a video presentation with converting the power point results into the form of a video presentation, with regard to the steps in making video presentations using Screencast-O-Matic or SOM application are as follows:

a. Download the SOM application from the internet and then install and save it on the desktop, the already installed app will appear.

b. Make presentation file in power point and record with SOM apps.

1) The process of recording in video form:

2) After SOM box appears to record the sound, web camera and started recording process power point presentation of the reader into a video presentation.

3) Recording using the camera so that the presenter can be seen and hosted on the presentation of this material.

4) Recording by SOM apps showing speakers use Web camera, click the name of your laptop (eg. Toshiba Web Camera)

5) Video presentation results are stored in a file and ready to be published either locally in class or published nationally and internationally on youtube

6) Video results are stored in a file, click publish as file, if you want to directly uploaded to the internet just click publish as SOM or You Tobe.

c. Save as video file storage, processes the results of the video presentation

d. Recording the results of changing the power point to video presentations of students attracted to MP4.
This application can help educators to provide certain materials to students if educators are unable to attend to fill hours of face-to-face directly. By utilizing the front camera on notebook or laptop monitor screen, educators can do learning activities or deliver learning materials that will be provided on that day. Any activity performed when making videos with this application will be recorded properly in detail either sound or movement of the cursor on the screen monitor.

This application is not limited to making videos with the camera, but this application is more leading to the recording computer monitor screen and any activity carried out on the monitor screen will be formatted into video form. So in addition to being able to record yourself with front camera, educators can also be combined with a Power Point application opens on the screen monitor and explain the teaching materials. Thus, educators do not lose the oppurtinity of quality teaching. Rather than just give additional tasks to students because there are activities from school to do, this could be used as one solution. Educators can also add comments below the video that has been made. Suppose further that activities should be done or given tasks that cannot be described by words alone but should be with certain notes.

\subsection{Screencast O Matic Application utilization in the process of learning Education Hindu}

Hindu religious education is to nurture all efforts of humanity, as well as the existing human resources leading to the formation of the whole person in accordance with the norms of the prevailing society. Thus, the purpose of the Hindu religious education focuses on three dimensions, namely: first, the formation of civilized human beings (human universal, consciousness). Second, the creation of religious beings, which has dimensions of spiritual, cultural, and scientific. Thirdly, awareness of human function as human beings, give adequate provision in the 
framework of the implementation of the function. The purpose of the Hindu religious education will be achieved when the selected educational material and taught with good precision.

The challenge facing the Hindu religious education as a subject is how educators are able to implement the Hindu religious education not only as a teaching of religious knowledge but also how directs students in order to have the qualities of faith, obedience and noble character. So it is not just religious education material taught knowledge about religion but how to guide and shape the personality of the students to have a strong faith and devotion, and his life are always adorned with noble morals wherever they are located and in whatever position they work. In this case the duty of educators are to educate.

When a school could not provide adequate facilities such as internet, elearning will be hard to do. Especially if that schools are lack of Hindu religious educators. For example, the schools are located in remote areas and the inability of the school bring in Hindu religious education teacher at any time, the use of this application can be done well. Educators are required to provide the science at that school can do the stages in making interactive video and then give it by e-mail to other fellow educators who are at the same field then ask help to play it on the class that they taught. Although there is no projector, it does not matter. Many household tools that can be used to create your own projector such as using a small cardboard boxes, glass bottles, and mirrors.

\section{CONCLUSION}

Utilization of Screencast $\mathrm{O}$ Matic Application provides the way of problems solving even though educators could not able to present any time directly to the class which was taught because of the situation and the specific conditions that do not allow them to attend, but the presence of educators still feels inside the roon, so that students do not miss the teaching materials and educators are able to run both their work properly. Utilizing existing technologies as an educator is important to do.

\section{REFERENCES}

Bart, M. (2010. Using Screen Capture Software to Help Reclaim Class Time. Missouri: Faculty Focus

Ferlazzo, Larry. 2013. English Language Learners Using Screencast-o-matic For Folktale Presentations. CA: Sacramento

Hamalik, Oemar. 2008. Kurikulum dan Pembelajaran. Jakarta: Sinar Grafika

Titib, I Made. 2003. Menumbuhkembangkan Pendidikan Budhi Pekerti Pada Anak (Perspektif Agama Hindu). Bandung: Ganeca Exact.

Wardani, Ayu Yuztia. 2015. Skripsi : Penggunaan Media Audio-Visual Screencast-O- Matic Sebagai Upaya Meningkatkan Hasil Belajar Siswa Pada Mata Pelajaran Sejarah Indonesia Kelas XI IIS 3 SMA Negeri 7 Malang. 